\title{
Learning for social-ecological change: A qualitative review of outcomes across empirical literature in natural resource management
}

Suškevičs, Monika ${ }^{\mathrm{a}, \mathrm{b}}$ *; Hahn, Thomas ${ }^{\mathrm{a}}$; Rodela, Romina ${ }^{\mathrm{c}, \mathrm{d}}$; Macura, Biljana ${ }^{\mathrm{e}}$; Pahl-Wostl, Claudia $^{\mathrm{f}}$

${ }^{a}$ Stockholm Resilience Centre, Stockholm University, Stockholm, Sweden; ${ }^{b}$ Institute of Agricultural and Environmental Sciences, Estonian University of Life Sciences, Tartu, Estonia; ${ }^{c}$ School of Natural Sciences, Technology and Environmental Studies, Södertörn University, Huddinge, Sweden; ${ }^{d}$ Laboratory of GeoInformation Science and Remote Sensing, Wageningen University, Wageningen, the Netherlands; ${ }^{e}$ MISTRAEviEM, Stockholm Environment Institute, Stockholm, Sweden; ${ }^{f}$ Institute of Environmental Systems Research, University of Osnabrück, Osnabrück, Germany

* Corresponding author, e-mail: monika.suskevics@emu.ee

\begin{abstract}
Learning is considered as a promising mechanism to cope with rapid environmental change. The implications of learning for natural resource management (NRM) have not been explored in-depth and the evidence on the topic is scattered across multiple sources. We provide a qualitative review of types of learning outcomes and consider their manifestations in NRM across selected empirical literature. We conducted a systematic search of the peer-reviewed literature $(\mathrm{N}=1223)$ and a qualitative meta-synthesis of included articles, with an explicit focus on learning outcomes and NRM changes $(\mathrm{N}=53)$. Besides social learning, we found several learning concepts used, including policy and transformative learning, and multiple links between learning and NRM reported. We observe that the development of skills, together with a systems-approach involving multilevel capacities, are decisive for implications of learning for NRM. Future reviews could systematically compare how primary research applies different learning concepts and discusses links between learning and NRM changes.
\end{abstract}

Keywords: adaptive co-management; general resilience; institutional change; qualitative metasynthesis; transformative change

\section{Introduction}

Notions of learning are gaining attention across the literature on natural resource management (NRM), e.g., adaptive co-management (Berkes 2009; Fabricius and Cundill 2014), but also in specific research fields as is water management (Mostert et al. 2007), forestry (Dedeurwaerdere 2009) and others. One of the main arguments for expanding these research domains to the study of learning is the assumption that there is potential in learning, as experienced by resource users, to address challenges associated with complexity and uncertainty in NRM (Armitage et al. 2008; Brugnach and Ingram 2012). For example, social learning has been proposed as a complementary governance mechanism to manage change in social-ecological systems (SES) (see Brown 2014; Ison et al. 2015). However, blurred links between learning and sustainability practices have frequently puzzled social-ecological research as well as NRM practice (Plummer and Armitage 2007; Armitage et al. 2008; Kristjanson et al. 2013). 
The NRM literature employs different terms and concepts to study learning. The choice of the concepts seems to relate to how assumptions about learning are linked to given outcomes. In this field of inquiry, three broad conceptualisations - social learning, transformative learning, and policy learning - are used most frequently in empirical research. We refer to these as 'learning concepts'.

These concepts vary across the contexts in which learning occurs. The difference is even more pronounced when it comes to the types of outcomes learning is supposed to support - as the NRM literature often uses different learning concepts for instrumental purposes. 'Social learning' as a conceptual construct (see Rodela 2014) is probably the most widely used term across the NRM literature. It denotes various collaborative and multi-loop processes leading to topic-oriented and relational outcomes at individual and collective levels (see Keen and Mahanty 2005; Muro and Jeffrey 2008; 2012), occasionally in relation to adaptive and transformative change (Pahl-Wostl 2009; 2015). The theory of transformative learning (as from Mezirow 1991) has also been applied in NRM research, sometimes in combination with notions of social learning (e.g. Wilner et al. 2012; Marschke and Sinclair 2009; Rodela 2013). Transformative learning has been used to emphasize two types of outcomes: change occurring in individuals' attitudes, values and frames of reference (Sinclair et al. 2008; Marschke and Sinclair 2009; (Diduck et al. 2012), but also the change of practices or individual actions (Wilner et al. 2012; Sinclair et al. 2008). Finally, theories of policy learning, deriving from political science, have recently gained attention in NRM research (Gerlak and Heikkila 2011; Sotirov and Memmler 2012). Policy learning theories usually seek to explain policy outcomes at more generic levels, by focusing on the learning experience of state officials, policy networks, or policy communities (Bennett and Howlett 1992; Hall 1993).

We provide a qualitative review of types of learning outcomes and consider their manifestations in NRM across selected empirical literature. In doing so, we include various learning concepts and NRM domains. Our approach adds to previous reviews in the following ways. First, while earlier reviews have considered what constitutes a learning outcome across selected literature (for instance: Cundill and Rodela 2012; Siebenhüner et al. 2016), links between learning outcomes and their possible wider implications in NRM have not been explored in this way before. Here, we review literature which has an explicit action-oriented focus that discusses outcomes from learning. We are aware that much of the literature on learning originates from disciplinary fields, e.g. psychology (van Boxtel et al. 2000), or sub-disciplines of pedagogy, like adult learning (Mezirow 1991). We focus on the learning processes that can lead to both types of outcomes: learning outcomes in terms of cognitive or relational change at the individual level (usually elaborated in psychology) as well as on broader management and policy change (frequently described in transdisciplinary fields such as NRM). Second, the conceptual background in existing reviews of NRM-literature on learning has either relied on the conceptual construct of social learning or on transformative learning theory (Sinclair et al. 2008; Diduck et al. 2012). We make a step forward and include other relevant learning concepts, such as policy learning, in our review, to explore a possible broader set of outcomes. Third, existing reviews have mostly employed systematic mapping or surveys of the literature (e.g. Rodela 2011; Ensor and Harvey 2015; Siebenhüner et al. 2016). Here, we use a novel methodology and undertake a qualitative in-depth exploration of included studies ( $\mathrm{N}=53$ publications). We present a transparent and replicable methodology for a qualitative literature review and synthesis applied for the first time in this field, to extract key aspects of interest. 
The review is divided as follows. In the next section, we introduce the analytical and methodological approach that guided our systematic literature searches, qualitative analysis, and synthesis. We then present and discuss our findings, and conclude with a reflection on the potential implications of our analysis for future research.

\section{Analytical framework}

For the systematic search of peer-reviewed literature and the qualitative synthesis, we developed an analytical framework with different categories of outcomes from learning (likely to be elaborated in the empirical NRM literature) (Figure 1). The framework facilitated initial classification of included articles and provided a basis for building a more comprehensive, and empirically grounded, synthesis framework of different types of outcomes from learning (see Section 4).

\subsection{Learning outcomes}

Current literature has described learning processes initiated top-down by government policies (Bull et al. 2008), bottom-up by individual actors (Folke et al. 2005) or by researchers and other 'external' stakeholders (Fabricius and Cundill 2014). We suggest that learning processes, including the scientific and political framing, participants, facilitation, resources, together with various contextual factors, determine learning outcomes (Figure 1). Learning outcomes can include cognitive changes (such as knowledge acquisition, altered individual beliefs: category 1.1 on Figure 1 and Table 1) and changes in relational dimensions, like the ways people relate to each other, or feel about specific topics (attitudes) (category 1.2) (Pahl-Wostl et al. 2007); Pahl-Wostl 2015). Moreover, learning outcomes often include the creation of shared knowledge (Muro and Jeffrey 2008). Some authors, especially those writing about social learning and transformative learning (e.g. Muro and Jeffrey 2008; 2012; Diduck et al. 2012), regard skills, including relational abilities for conflict resolution and technical abilities (e.g. specific expertise), as a separate learning outcome (category 1.3).

Cognitive, relational and skill-related changes are foremost associated with individual learners, and may, or may not, induce concerted action (Kristjanson et al. 2013). In contrast, theories on policy learning assume that learning agents are larger entities, such as policy networks or governments (Bennett and Howlett 1992). To link individual learning outcomes with their manifestations in NRM we added two categories of learning outcomes. First, action-orientation (category 1.4) refers to learning outcomes manifested as networks, e.g. stakeholder alliances, formed with the intentions to influence decision-making concerning specific NRM problems. However, such networks, with the trust and leadership they generate, may also enhance wider capacity beyond the specific initiative (category 1.5). This can result in tangible outcomes in other policy arenas and can enhance general societal resilience, i.e. the adaptive and transformative capacity of a society to respond to external pressures (Folke et al. 2010). 


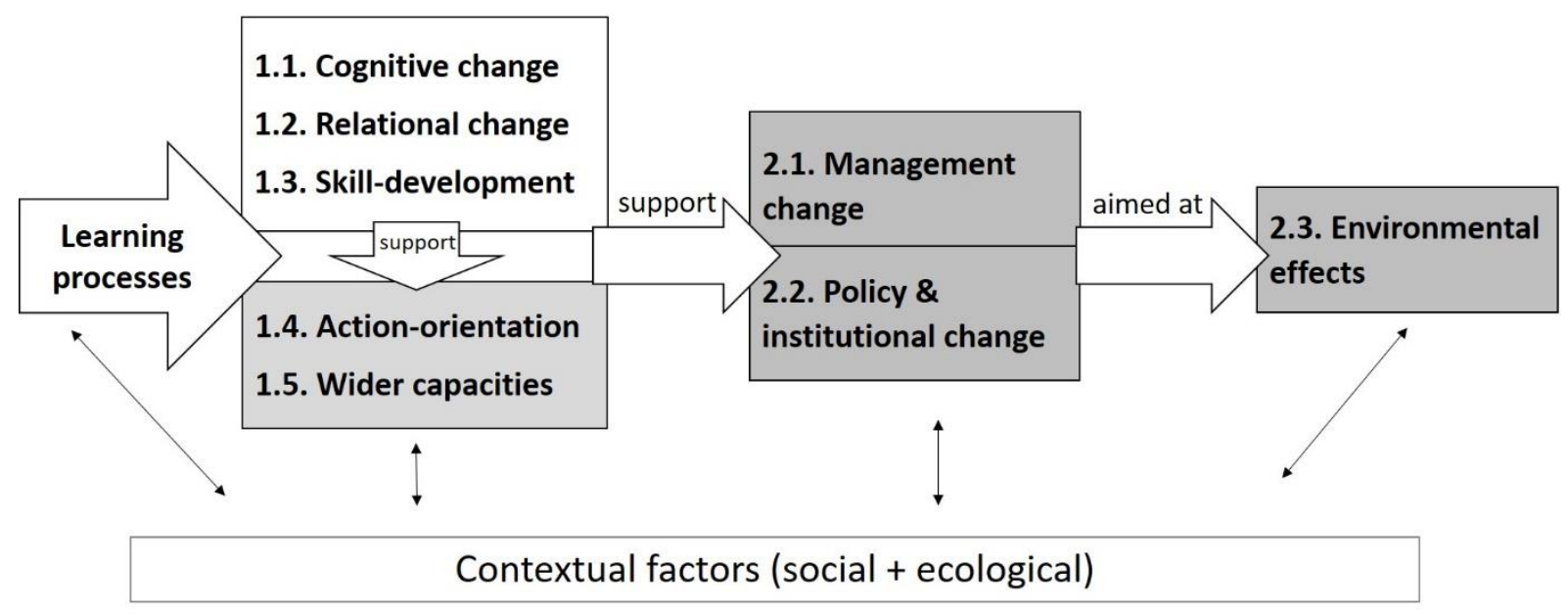

change appears mostly at:

... individual levels

...collective \& systemic levels

Figure 1. Framework to guide analysis of types of learning outcomes and their manifestations in NRM.

\subsection{Manifestations of learning outcomes in NRM}

Practice-oriented changes in NRM are often considered as ultimate goals of learning-based interventions (Koontz and Thomas 2006; Plummer and Armitage 2007). Yet, the question is: Under which conditions does learning lead to tangible outcomes in the NRM domain? Policy learning theories, for example, draw a rather direct link between learning and policy change. Learning outcomes here can be altered preferences, beliefs or behavioural change of state officials, but also new strategies, rules, or policies (Gerlak and Heikkila 2011). The literature on transformative learning views learning foremost as a process whereby one's worldview changes, with the aim to "break from unsustainable human-environmental interactions" (Diduck et al. 2012:172), but also to "effect changes in the system, in institutions, or in social practices" (Marschke and Sinclair 2009:207).

We understand learning-related NRM outcomes as "manifestations of learning outcomes in the NRM domain" with three sub-categories: management change (category 2.1, Figure 1 and Table 1), policy and institutional change (category 2.2), which are all ultimately targeted at environmental change (category 2.3). We define 'management change' as a change in the operational decisions aimed at achieving specific goals (Armitage et al. 2012), i.e. a change in practices concerning what is done in a specific situation (Borrini-Feyerabend et al. 2006). 'Policy change' evolves around agreements at different organisational levels, such as management plans and other documents concerning future actions. 'Institutional change' includes changes in formal institutions, such as legislation, regulations and other officially enforced subsidiary rules (Bromley 1991) but also in informal institutions, like social norms or customs (Paavola 2007). The latter are not as tangible as formal institutions but can create legitimacy for implementing them (Hahn 2011). 
Table 1. Summary of definitions of learning outcomes and their NRM manifestations.

\begin{tabular}{|c|c|c|c|}
\hline & Outcome type & Definition & Reference \\
\hline \multirow{5}{*}{ 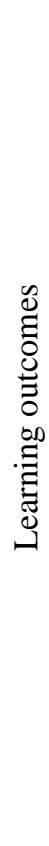 } & $\begin{array}{l}\text { 1.1. Cognitive } \\
\text { change }\end{array}$ & $\begin{array}{l}\text { Acquisition of knowledge by individuals and groups; } \\
\text { creation of shared knowledge on, e.g. how society depends } \\
\text { on ecosystems. }\end{array}$ & $\begin{array}{l}\text { Pahl-Wostl et al. } \\
\text { 2007; Muro and } \\
\text { Jeffrey 2008; } \\
\text { Pahl-Wostl 2015 }\end{array}$ \\
\hline & $\begin{array}{l}\text { 1.2. Relational } \\
\text { change }\end{array}$ & $\begin{array}{l}\text { Changes in individuals' feelings towards each other, and } \\
\text { attitudes towards specific topics. }\end{array}$ & $\begin{array}{l}\text { Pahl-Wostl et al. } \\
\text { 2007; Muro and } \\
\text { Jeffrey 2008; } \\
\text { Pahl-Wostl 2015 }\end{array}$ \\
\hline & $\begin{array}{l}\text { 1.3. Skill- } \\
\text { development }\end{array}$ & $\begin{array}{l}\text { Changes in relational abilities for conflict resolution and } \\
\text { technical abilities, e.g. specific expertise. }\end{array}$ & $\begin{array}{l}\text { Muro and Jeffrey } \\
\text { 2008; 2012; } \\
\text { Diduck et al. } 2012\end{array}$ \\
\hline & $\begin{array}{l}\text { 1.4. Action- } \\
\text { orientation }\end{array}$ & $\begin{array}{l}\text { Changes in networks, e.g. stakeholder alliances, formed with } \\
\text { the intentions to influence decision-making concerning } \\
\text { specific NRM problems. }\end{array}$ & $\begin{array}{l}\text { Folke et al. 2010; } \\
\text { Crona and Parker } \\
2012\end{array}$ \\
\hline & $\begin{array}{l}\text { 1.5. Wider } \\
\text { capacities }\end{array}$ & $\begin{array}{l}\text { Changes in wider social capacities beyond specific } \\
\text { initiatives; these can also result in tangible outcomes in other } \\
\text { policy arenas. }\end{array}$ & $\begin{array}{l}\text { Plummer and } \\
\text { Armitage 2007; } \\
\text { Folke et al. } 2010\end{array}$ \\
\hline \multirow{3}{*}{ 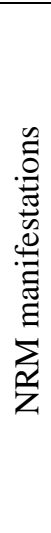 } & $\begin{array}{l}\text { 2.1. Management } \\
\text { change }\end{array}$ & $\begin{array}{l}\text { Changes in the operational decisions targeted at achieving } \\
\text { specific goals, i.e. changes in practices, what is done in a } \\
\text { given situation. }\end{array}$ & $\begin{array}{l}\text { Borrini- } \\
\text { Feyerabend et al. } \\
\text { 2006; Armitage et } \\
\text { al. } 2012\end{array}$ \\
\hline & $\begin{array}{l}\text { 2.2. Policy and } \\
\text { institutional change }\end{array}$ & $\begin{array}{l}\text { Policy change - achieved agreements, such as management } \\
\text { plans and other documents concerning future actions. } \\
\text { Institutional change - changes in formal rules (e.g. } \\
\text { legislation) but also in informal institutions, like social } \\
\text { norms. }\end{array}$ & $\begin{array}{l}\text { Bromley 1991; } \\
\text { Paavola } 2007\end{array}$ \\
\hline & $\begin{array}{l}\text { 2.3. Environmental } \\
\text { effects }\end{array}$ & $\begin{array}{l}\text { Changes in environmental conditions, e.g. habitat, water or } \\
\text { air quality. }\end{array}$ & $\begin{array}{l}\text { Koontz et al. } \\
\text { 2006; Plummer } \\
\text { and Armitage } \\
2007\end{array}$ \\
\hline
\end{tabular}

However, it is not easy to separate learning outcomes from their manifestations in NRM, and moreover, to trace them causally back to learning. For example, multi-stakeholder management networks can foster voluntary action-oriented collaboration (i.e. direct learning outcome) (Schultz et al. 2007), but the management plans such networks formulate can be viewed as policy change (i.e. NRM change). There is also an attribution problem in establishing causal links between processes and their outcomes (Plummer and Armitage 2007). This is due to the characteristics of learning processes (e.g. their length, iterative nature) and the contextual factors that may affect NRM outcomes, but are not directly related to learning. In our review, we are interested in how links between different outcomes are constructed by the authors of the included publications; however, we do not aim to investigate causal relationships between learning and their outcomes. 


\section{Methodology}

To create a comprehensive evidence synthesis that captures relevant articles on learning outcomes in the NRM literature, we combined several methodological approaches. We started with a systematic literature search, adapting methods from systematic reviews (Petticrew and Roberts 2006; Haddaway et al. 2015). The purpose was to capture all relevant empirical articles discussing learning and outcomes related to NRM. We then applied qualitative meta-synthesis (Hannes and Lockwood 2012), combining framework synthesis (deductive approach) with principles from thematic and narrative synthesis (explorative and interpretive methodologies to study the phenomena in-depth). Using a predefined set of criteria (Figure 2), the first author searched the literature, screened, included and coded relevant studies. All decisions connected to these review stages were regularly discussed with the second author and the others. Differences in opinions were discussed and where needed, decisions were modified accordingly.

Most of the reviewed publications are designed as qualitative case studies. This implies that their methodological approach does not follow experimental and other similar setups which would allow tracing causal relations better. Thus, we do not aim to test correlations or causal links between learning and its outcomes; but aim to provide a qualitative summary and synthesis of how these links have been described in the literature. For these reasons, we have also not undertaken any validity appraisal of the included articles.

\subsection{Systematic searches}

We undertook a scoping search in the Web of Science (WoS) testing several search strings, to find the most optimal and comprehensive combination of search terms for our research objective. Our final search was conducted in November 2015 in the WoS Core Collection database (citation indexes: SCIE, SSCI, CPCI-Sci, CPCI-SocSci \& Hum, ESCI). We searched on the topic (including keywords, titles, and abstracts) in the English language and with no time limitations. Our final search string combined two substrings: terms referring to theories or concepts of learning (1), and NRM domains (2).

(1) "social learning" OR "experiential learning" OR "participatory learning" OR "collaborative learning" OR "societal learning" OR "transformative learning" OR "policy learning"

AND

(2) forest* OR ecosystem* OR ecolog* OR water OR biodiversity OR agricultur* OR wetland* OR landscape* OR climate OR "land use" OR restor*

This string resulted in 1223 hits. Figure 2 depicts searching, screening, and inclusion process and shows exclusion criteria. References were downloaded to endnote and screened for relevance in two stages: first at the title and abstract, and later at the full-text level. We retrieved full-text articles digitally (as PDF files) and where needed, we used subscription of Stockholm University. 


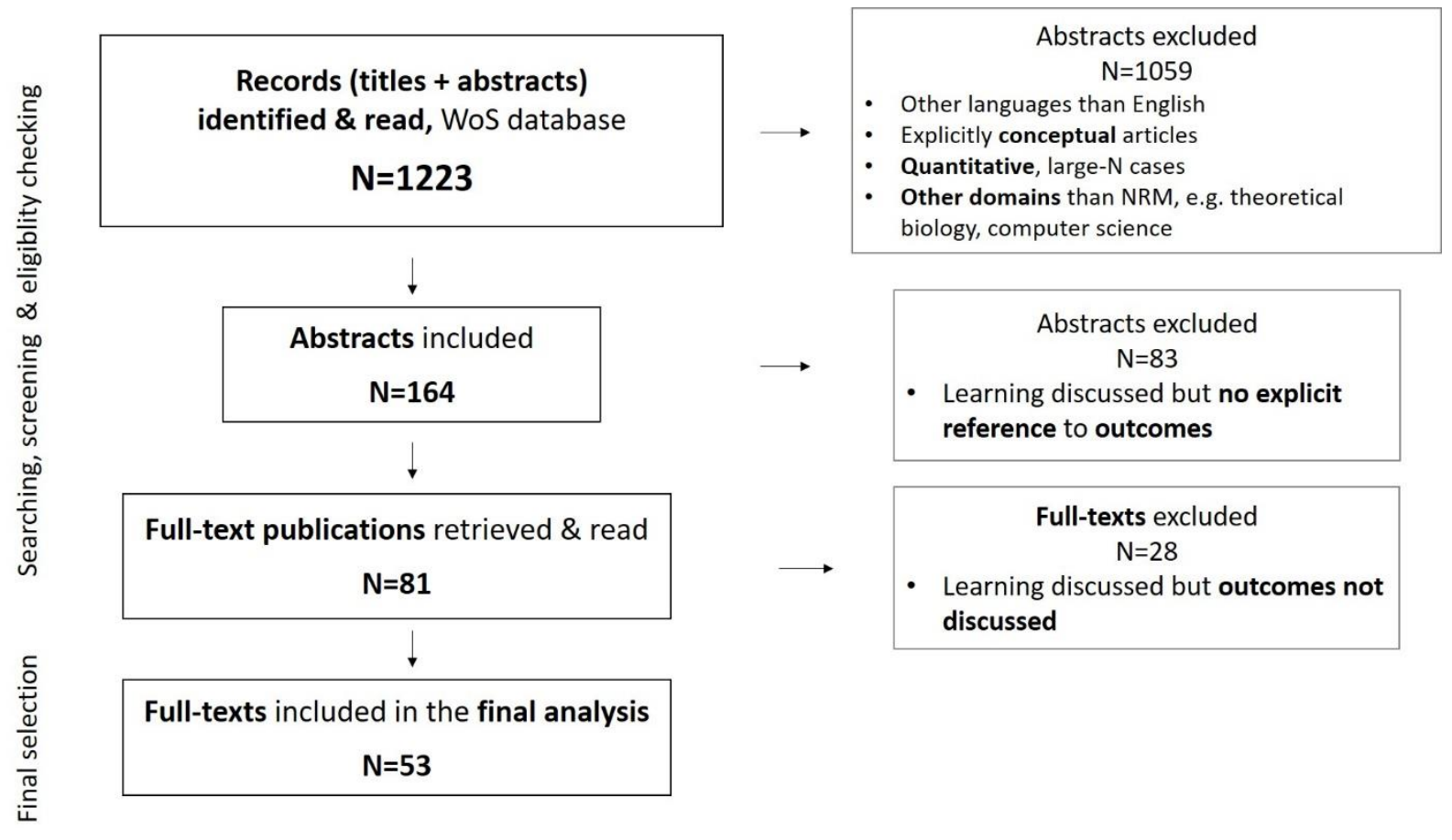

Figure 2. Flowchart of searching, screening, and inclusion of relevant articles.

Titles and abstracts were screened to exclude non-NRM papers and explicitly conceptual articles (Figure 2). Then, the remaining 164 abstracts were read again to exclude articles not discussing learning outcomes and NRM manifestations, but focus on the learning process only. The remaining 81 articles were read full-text. At this stage, we excluded 28 articles for not discussing learning outcomes or NRM manifestations. We included 53 relevant articles for our review (see Additional references for the reviewed publications).

\subsection{Framework, thematic, and narrative syntheses}

After including all relevant literature we employed a framework synthesis to guide the coding of the 53 included articles. This was done according to the eight pre-determined outcome categories (from 1.1 to 2.3 on Figure 1). Framework synthesis uses an a priori framework, based on background literature, to extract and synthesise findings from primary studies (Carroll et al. 2013), although new topics can be added to the framework during the synthesis. Additionally, to gain a deeper understanding of how outcomes are discussed in the 53 articles, we employed a more interpretative thematic and textual narrative syntheses (Paterson 2012). First, thematic synthesis combines approaches from meta-ethnography and grounded theory (Barnett-Page and Thomas 2009), using an explorative approach where themes are developed by constant comparisons. For each of the eight outcome categories, we developed key themes (Figure 4 below) by applying (1) line-by-line coding, searching for commonalities and differences between the studies; (2) organising codes into descriptive themes, and (3) developing analytical themes from descriptive themes (third-order interpretation). Second, textual narrative synthesis is "an exploration of ways of understanding a particular phenomenon across disciplines and research traditions" in which emerging storylines are identified within the study domain (Paterson 2012:15). The approach strives to summarise different types of 
qualitative and quantitative data, reporting on study characteristics, the context and findings according to a standard format, and comparing these across case studies (Barnett-Page and Thomas 2009). Basic characteristics (e.g. bibliographic details, topical focus, theoretical and methodological background) and the main topics of interest based on our research objective were extracted in a spreadsheet that we used for the analysis. When presenting results from thematic and narrative syntheses given in the following (Section 4), we provide many examples and direct quotes to retain transparency and to show the original constructs used in the reviewed studies.

\subsection{Limitations}

Before we present and discuss our findings, we identify some limitations of this review. First, due to time and resource constrains we have not included scientific books or book chapters and grey literature. Second, our literature search was confined to English. Hence, although our sample is global, the resulting 53 articles are not exhaustive in representing all empirical literature on learning in the field of NRM. Third, since the literature does not have common definitions of terms on learning, it was difficult to design an efficient search strategy. Our initial searches for "learning" returned an unmanageable number of hits $(>400,000$ hits in WoS). Therefore we added seven NRM domains to the search string, to increase the precision of our search. Fourth, search results inherently depend on the terminology used. For example, some literature describes outcomes in the NRM domain, but instead of "learning" the abstracts employ related concepts, like "stakeholder collaboration", "trust-building", "networking", "adaptive co-management" or "governance", and were thus not captured in our search. Finally, as the included articles rely on related, but still different, theoretical backgrounds, it was evident that the different authors often use specific concepts (e.g. learning outcomes) differently. Therefore, during coding and prior to the final categorisation of studies and development of analytical themes we were constantly returning to the original studies to gain contextual understanding.

\section{Results and Discussion}

\subsection{General trends in the selected literature}

We found and included 53 relevant articles in this review (see Additional references for the reviewed publications for a full list). Most articles report single case studies, while some make comparative analyses of several cases, sometimes in different regions (Figure 3d). Connecting learning to NRM outcomes empirically seems to be a rather new research endeavour: the first article in our sample was published in 2004 and overall, not many articles were published up to 2011 (Figure 3a). This research is coordinated by interdisciplinary research centres and published in 29 different journals of which 'Ecology \& Society' was the most common (Appendices 1 and 2 [online supplemental data]). 


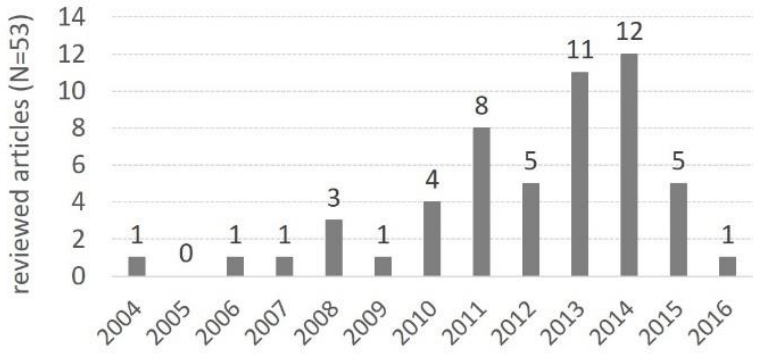

a) publication year

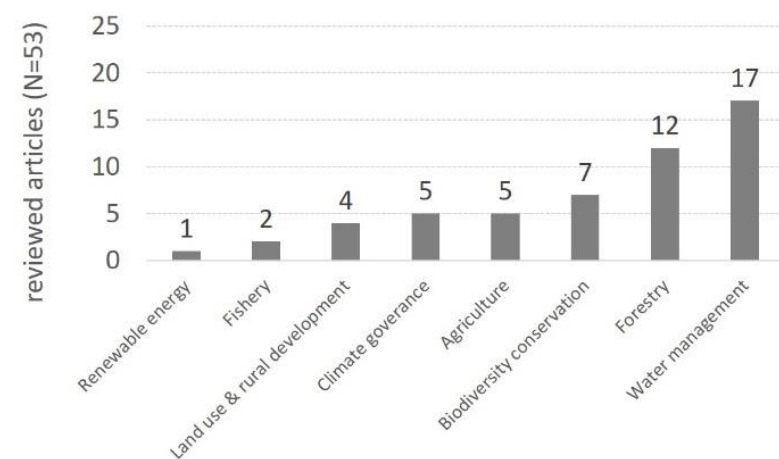

c) NRM domains: thematic focus

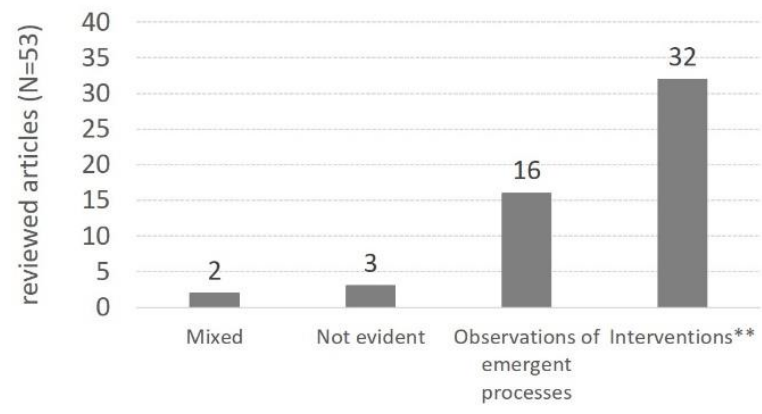

e) methodological approach

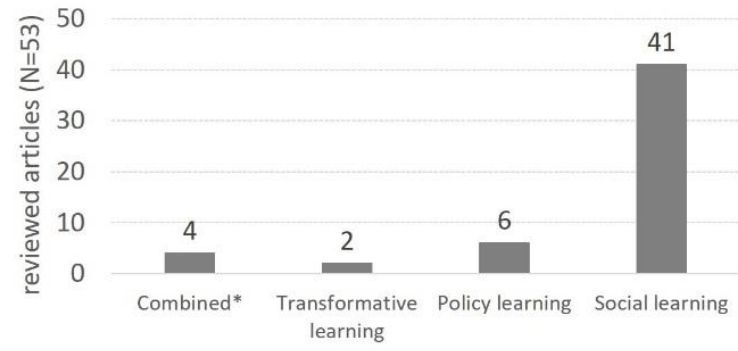

b) learning concepts

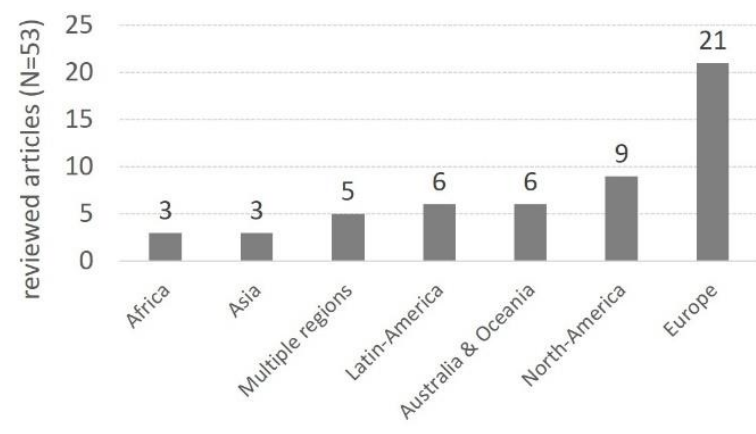

d) region

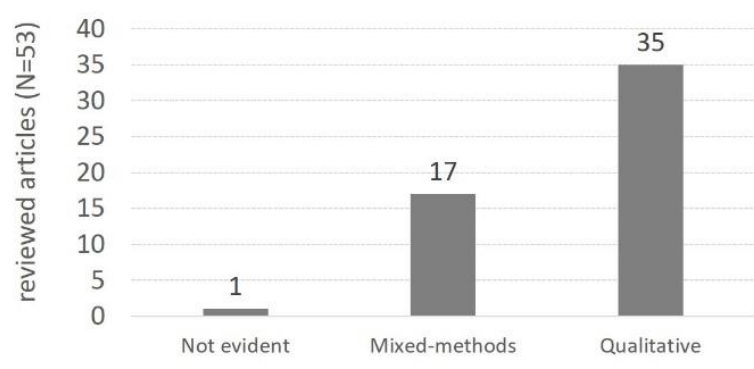

f) types of evidence

Figure 3. Distribution of included articles by a) publication year; b) learning concepts*; c) NRM domains; d) region; e) methodological approach**; and f) types of evidence. Note: b)*Combined: social + policy learning; collaborative + social learning; social + societal learning; e)**Interventions: e.g. participatory action research; government-led participation.

Reviewed publications rely prevalently on the conceptual construct of "social learning" (41 articles, Figure 3b), but also on theories of policy learning (6) and transformative learning (2). Other learning concepts and terms were also used, such as "collaborative learning" and "societal learning". In some articles, learning concepts were used in combination with each other.

The sample of selected articles covers a wide spectrum of NRM domains (Figure 3c). Similarly to earlier reviews focused on the social learning literature (e.g. Rodela 2013) water management $(32 \%)$ is dominating, but surprisingly, climate governance, land use, and rural development are also well-represented in our sample.

Most of the included articles were reporting on empirical cases from Europe (Figure 3d), mainly the Netherlands (5 articles), Sweden (5) and Germany (4), but the sample also contained cases from Latin America (e.g. Brazil, Peru, and Bolivia), Asia (e.g. Korea, Nepal, and India), Africa 
(e.g. South-Africa, Mozambique, and Mali), and there were seven cases from the US and two from Canada.

As the methodological approaches, most of the reviewed articles (32) used interventions, e.g. participatory action research or government-driven participation to activate learning and change (Figure 3e). A smaller subset of articles was based on observations of emerging processes (e.g. day-to-day decision-making). Most of the articles (35) employed qualitative research designs with in-depth analysis of one or a small number of case studies (Figure 3f). Mixed-methods research designs were employed to a lesser extent (17), combining qualitative and quantitative approaches in standardized surveys or field experiments.

We now present and discuss the results from the qualitative meta-synthesis, which are summarised below in the "synthesis framework" (Figure 4).

\subsection{Learning outcomes}

Forty-two (79\%) articles report on different types of learning outcomes (Table 2). In the following four Sections (4.2.1.-4.2.4.) we discuss the emerging themes for each outcome category as identified in our analytical framework.

Table 2. Outcome categories in the analysed publications.

\begin{tabular}{|c|c|c|c|c|c|c|c|c|c|c|}
\hline \multicolumn{3}{|c|}{ Reviewed articles } & \multicolumn{5}{|c|}{ Learning outcomes } & \multicolumn{3}{|c|}{ NRM manifestations } \\
\hline No. & Author(s) & Year & $\begin{array}{c}1.1 . \\
\text { Cogni- } \\
\text { tive } \\
\text { change }\end{array}$ & $\begin{array}{c}1.2 . \\
\text { Rela- } \\
\text { tional } \\
\text { change }\end{array}$ & $\begin{array}{c}\text { 1.3. } \\
\text { Skills }\end{array}$ & $\begin{array}{l}1.4 . \\
\text { Action- } \\
\text { orien- } \\
\text { tation }\end{array}$ & $\begin{array}{l}\text { 1.5. Wider } \\
\text { capacities }\end{array}$ & $\begin{array}{c}2.1 . \\
\text { Mana- } \\
\text { gement } \\
\text { change }\end{array}$ & $\begin{array}{c}2.2 . \\
\text { Policy \& } \\
\text { institu- } \\
\text { tional } \\
\text { change }\end{array}$ & $\begin{array}{c}2.3 . \\
\text { Environ- } \\
\text { mental } \\
\text { effects }\end{array}$ \\
\hline 1 & Albert et al. & 2012 & $\mathrm{x}$ & $\mathrm{x}$ & $\mathrm{X}$ & & $\mathrm{x}$ & & $\mathrm{x}$ & \\
\hline 2 & $\begin{array}{l}\text { Alkan- } \\
\text { Olsson et } \\
\text { al. }\end{array}$ & 2011 & $\mathrm{x}$ & & & & & & $\mathrm{x}$ & \\
\hline 3 & $\begin{array}{l}\text { Armitage et } \\
\text { al. }\end{array}$ & 2011 & $\mathrm{x}$ & & $\mathrm{x}$ & & $\mathrm{x}$ & $\mathrm{x}$ & $\mathrm{x}$ & \\
\hline 4 & $\begin{array}{l}\text { Balazs \& } \\
\text { Lubell }\end{array}$ & 2014 & $\mathrm{x}$ & $\mathrm{x}$ & & $\mathrm{x}$ & & & & \\
\hline 5 & $\begin{array}{l}\text { Benson et } \\
\text { al. }\end{array}$ & 2016 & $\mathrm{x}$ & & & & & & & \\
\hline 6 & $\begin{array}{l}\text { Biedenweg } \\
\& \text { Monroe }\end{array}$ & 2013 & $\mathrm{x}$ & & $\mathrm{x}$ & $\mathrm{x}$ & & & $\mathrm{x}$ & \\
\hline 7 & $\begin{array}{l}\text { Bos \& } \\
\text { Brown }\end{array}$ & 2012 & $\mathrm{x}$ & $\mathrm{x}$ & & & & $\mathrm{x}$ & $\mathrm{x}$ & \\
\hline 8 & Boyd et al. & 2014 & & & & & & & $\mathrm{x}$ & \\
\hline 9 & Cheng et al. & 2011 & $\mathrm{x}$ & & $\mathrm{x}$ & & $\mathrm{x}$ & $\mathrm{x}$ & $\mathrm{x}$ & $\mathrm{x}$ \\
\hline 10 & Cundill & 2010 & & & & & & & $\mathrm{x}$ & \\
\hline 11 & $\begin{array}{l}\text { D'Angelo \& } \\
\text { Brunstein }\end{array}$ & 2014 & $\mathrm{x}$ & $\mathrm{x}$ & $\mathrm{x}$ & & $\mathrm{x}$ & $\mathrm{X}$ & $\mathrm{x}$ & \\
\hline 12 & $\begin{array}{l}\text { Dana \& } \\
\text { Nelson }\end{array}$ & 2012 & $\mathrm{x}$ & $\mathrm{x}$ & & & & & & \\
\hline 13 & Hahn et al. & 2006 & $\mathrm{x}$ & $\mathrm{x}$ & & $\mathrm{X}$ & & $\mathrm{x}$ & $\mathrm{X}$ & $\mathrm{X}$ \\
\hline
\end{tabular}




\begin{tabular}{|c|c|c|c|c|c|c|c|c|c|c|}
\hline \multicolumn{3}{|c|}{ Reviewed articles } & \multicolumn{5}{|c|}{ Learning outcomes } & \multicolumn{3}{|c|}{ NRM manifestations } \\
\hline No. & Author(s) & Year & $\begin{array}{c}\text { l.1. } \\
\text { Cogni- } \\
\text { tive } \\
\text { change }\end{array}$ & $\begin{array}{c}\text { l.2. } \\
\text { Rela- } \\
\text { tional } \\
\text { change }\end{array}$ & $\begin{array}{c}1.3 . \\
\text { Skills }\end{array}$ & $\begin{array}{c}1.4 . \\
\text { Action- } \\
\text { orien- } \\
\text { tation }\end{array}$ & $\begin{array}{l}\text { 1.5. Wider } \\
\text { capacities }\end{array}$ & $\begin{array}{c}2.1 . \\
\text { Mana- } \\
\text { gement } \\
\text { change }\end{array}$ & $\begin{array}{c}2.2 . \\
\text { Policy \& } \\
\text { institu- } \\
\text { tional } \\
\text { change } \\
\end{array}$ & $\begin{array}{c}2.3 . \\
\text { Environ- } \\
\text { mental } \\
\text { effects }\end{array}$ \\
\hline 14 & Head & 2014 & & & & & & $\mathrm{x}$ & $\mathrm{x}$ & \\
\hline 15 & Hilden & 2011 & $\mathrm{x}$ & & & & & & $\mathrm{x}$ & \\
\hline 16 & $\begin{array}{l}\text { Hordijk et } \\
\text { al. }\end{array}$ & 2014 & $\mathrm{x}$ & $\mathrm{x}$ & & & & & $\mathrm{x}$ & \\
\hline 17 & $\begin{array}{l}\text { Hoverman } \\
\text { et al. }\end{array}$ & 2011 & $\mathrm{x}$ & $\mathrm{x}$ & & & & & & \\
\hline 18 & $\begin{array}{l}\text { Huntjens et } \\
\text { al. }\end{array}$ & 2011 & $\mathrm{x}$ & & & $\mathrm{x}$ & & $\mathrm{x}$ & $\mathrm{x}$ & \\
\hline 19 & Hurlbert & 2013 & $\mathrm{x}$ & & & $\mathrm{x}$ & & $\mathrm{x}$ & & \\
\hline 20 & $\begin{array}{l}\text { Johannesen } \\
\text { \& Hahn }\end{array}$ & 2013 & $\mathrm{x}$ & & & $\mathrm{x}$ & & $\mathrm{x}$ & $\mathrm{x}$ & \\
\hline 21 & $\begin{array}{l}\text { Kumler \& } \\
\text { Lemos }\end{array}$ & 2008 & $\mathrm{x}$ & & & & & & $\mathrm{x}$ & \\
\hline 22 & Lebel et al. & 2010 & $\mathrm{x}$ & & & & & & $\mathrm{x}$ & \\
\hline 23 & $\begin{array}{l}\text { Lee \& } \\
\text { Krasny }\end{array}$ & 2015 & & & & & & $\mathrm{x}$ & $\mathrm{x}$ & \\
\hline 24 & $\begin{array}{l}\text { Leys \& } \\
\text { Vanclay }\end{array}$ & 2011 & $\mathrm{x}$ & $\mathrm{x}$ & & & & & & \\
\hline 25 & $\begin{array}{l}\text { Madsen \& } \\
\text { Noe }\end{array}$ & 2012 & & & & $\mathrm{x}$ & & & & \\
\hline 26 & $\begin{array}{l}\text { McDougall } \\
\text { et al. }\end{array}$ & 2013 & & $\mathrm{x}$ & & & & & & \\
\hline 27 & Maynard & 2015 & $\mathrm{x}$ & & & & & $\mathrm{x}$ & & \\
\hline 28 & $\begin{array}{l}\text { Menzel \& } \\
\text { Buchecker }\end{array}$ & 2013 & $\mathrm{x}$ & $\mathrm{x}$ & $\mathrm{x}$ & & $\mathrm{x}$ & & $\mathrm{x}$ & \\
\hline 29 & $\begin{array}{l}\text { Moellenka } \\
\text { mp et al. }\end{array}$ & 2010 & $\mathrm{x}$ & & & $\mathrm{x}$ & $\mathrm{x}$ & & $\mathrm{x}$ & \\
\hline 30 & $\begin{array}{l}\text { Murillo et } \\
\text { al. }\end{array}$ & 2015 & $\mathrm{x}$ & & & & & & & \\
\hline 31 & $\begin{array}{l}\text { Nguyen et } \\
\text { al. }\end{array}$ & 2014 & $\mathrm{x}$ & $\mathrm{x}$ & & & & & $\mathrm{x}$ & \\
\hline 32 & Nykvist & 2014 & & & & & & $\mathrm{x}$ & & \\
\hline 33 & $\begin{array}{l}\text { Olsson et } \\
\text { al. }\end{array}$ & 2004 & $\mathrm{x}$ & $\mathrm{x}$ & & $\mathrm{x}$ & & $\mathrm{x}$ & $\mathrm{x}$ & $\mathrm{x}$ \\
\hline 34 & $\begin{array}{l}\text { Pahl-Wostl } \\
\text { et al. }\end{array}$ & 2013 & $\mathrm{x}$ & & & $\mathrm{x}$ & & $\mathrm{x}$ & $\mathrm{x}$ & \\
\hline 35 & $\begin{array}{l}\text { Puente- } \\
\text { Rodriguez } \\
\text { et al. }\end{array}$ & 2015 & $\mathrm{x}$ & & & & & $\mathrm{x}$ & $\mathrm{x}$ & \\
\hline 36 & $\begin{array}{l}\text { Puszkin \& } \\
\text { Esnard }\end{array}$ & 2009 & & & & & & & $\mathrm{x}$ & \\
\hline 37 & Rist et al. & 2007 & $\mathrm{x}$ & & & $\mathrm{x}$ & $\mathrm{x}$ & & $\mathrm{x}$ & \\
\hline 38 & $\begin{array}{l}\text { Schneider } \\
\text { et al. }\end{array}$ & 2012 & & & & & & $\mathrm{x}$ & & \\
\hline
\end{tabular}




\begin{tabular}{|c|c|c|c|c|c|c|c|c|c|c|}
\hline \multicolumn{3}{|c|}{ Reviewed articles } & \multicolumn{5}{|c|}{ Learning outcomes } & \multicolumn{3}{|c|}{ NRM manifestations } \\
\hline No. & Author(s) & Year & $\begin{array}{l}\text { l.1. } \\
\text { Cogni- } \\
\text { tive } \\
\text { change }\end{array}$ & $\begin{array}{c}\text { 1.2. } \\
\text { Rela- } \\
\text { tional } \\
\text { change }\end{array}$ & $\begin{array}{c}\text { 1.3. } \\
\text { Skills }\end{array}$ & $\begin{array}{l}1.4 . \\
\text { Action- } \\
\text { orien- } \\
\text { tation }\end{array}$ & $\begin{array}{l}\text { 1.5. Wider } \\
\text { capacities }\end{array}$ & $\begin{array}{c}2.1 . \\
\text { Mana- } \\
\text { gement } \\
\text { change }\end{array}$ & $\begin{array}{c}2.2 . \\
\text { Policy \& } \\
\text { institu- } \\
\text { tional } \\
\text { change }\end{array}$ & \begin{tabular}{|c|}
2.3. \\
Environ- \\
mental \\
effects
\end{tabular} \\
\hline 39 & Secco et al. & 2011 & $\mathrm{x}$ & $\mathrm{x}$ & & & & & $\mathrm{x}$ & \\
\hline 40 & $\begin{array}{l}\text { Sendzimir } \\
\text { et al. }\end{array}$ & 2010 & $\mathrm{x}$ & & & $\mathrm{x}$ & & $\mathrm{x}$ & $\mathrm{x}$ & \\
\hline 41 & \begin{tabular}{|l|} 
Shaw \& \\
Kristjanson
\end{tabular} & 2014 & $\mathrm{x}$ & & & & & $\mathrm{x}$ & $\mathrm{x}$ & \\
\hline 42 & $\begin{array}{l}\text { Sims \& } \\
\text { Sinclair }\end{array}$ & 2008 & $\mathrm{x}$ & $\mathrm{x}$ & $\mathrm{x}$ & & & $\mathrm{x}$ & & $\mathrm{x}$ \\
\hline 43 & $\begin{array}{l}\text { Sinclair et } \\
\text { al. }\end{array}$ & 2013 & $\mathrm{x}$ & $\mathrm{x}$ & $\mathrm{x}$ & & & $\mathrm{x}$ & & $\mathrm{x}$ \\
\hline 44 & Sol et al. & 2013 & $\mathrm{x}$ & $\mathrm{x}$ & & & & $\mathrm{x}$ & & \\
\hline 45 & Smith et al. & 2015 & $\mathrm{x}$ & & & $\mathrm{x}$ & & & & \\
\hline 46 & $\begin{array}{l}\text { Tidball et } \\
\text { al. }\end{array}$ & 2010 & $\mathrm{x}$ & & $\mathrm{x}$ & & & $\mathrm{x}$ & & $\mathrm{x}$ \\
\hline 47 & $\begin{array}{l}\text { Van Assche } \\
\text { et al. }\end{array}$ & 2013 & & & & & & $\mathrm{x}$ & $\mathrm{x}$ & \\
\hline 48 & $\begin{array}{l}\text { Van } \\
\text { Gossum et } \\
\text { al. }\end{array}$ & 2008 & & & & & & & $\mathrm{x}$ & \\
\hline 49 & \begin{tabular}{|l|} 
Vinke-de \\
Kruijf et al.
\end{tabular} & 2014 & $\mathrm{x}$ & $\mathrm{x}$ & $\mathrm{x}$ & & $\mathrm{x}$ & & $\mathrm{x}$ & \\
\hline 50 & Wallis et al. & 2013 & $\mathrm{x}$ & & & & & & $\mathrm{x}$ & $\mathrm{x}$ \\
\hline 51 & $\begin{array}{l}\text { Watanabe } \\
\text { et al. }\end{array}$ & 2014 & $\mathrm{x}$ & & & & & $\mathrm{x}$ & & \\
\hline 52 & Wise & 2014 & & & & & & & $\mathrm{x}$ & \\
\hline 53 & Yuen et al. & 2013 & $\mathrm{x}$ & & & & & & & \\
\hline
\end{tabular}

\subsubsection{Cognitive change}

Consistent with earlier research (e.g. (Baird et al. 2014), we found that cognitive change is a learning outcome reported in a large subset of included articles (42 articles, 79\%). A closer look at them revealed that articles have most commonly reported about: (1) the acquisition and cocreation of knowledge in specific domains, and (2) enhanced comprehension of a problem domain (Figure 4).

Acquiring and co-creating knowledge on specific aspects included results from participatory action-research endeavours, such as Albert et al. (2012) reporting on increased level of knowledge about potential climate change impacts and adaptation strategies (Germany) or Menzel and Buchecker (2013) describing how the participants of river restoration projects gained ecological knowledge (Switzerland). Similarly, Hordijk et al. (2011) report on a growing awareness about the finite value of water resources (Brazil), and Hoverman et al. (2011) report 
on how participants of workshops in river restoration projects acquired knowledge during integrated catchment planning (Solomon Islands).

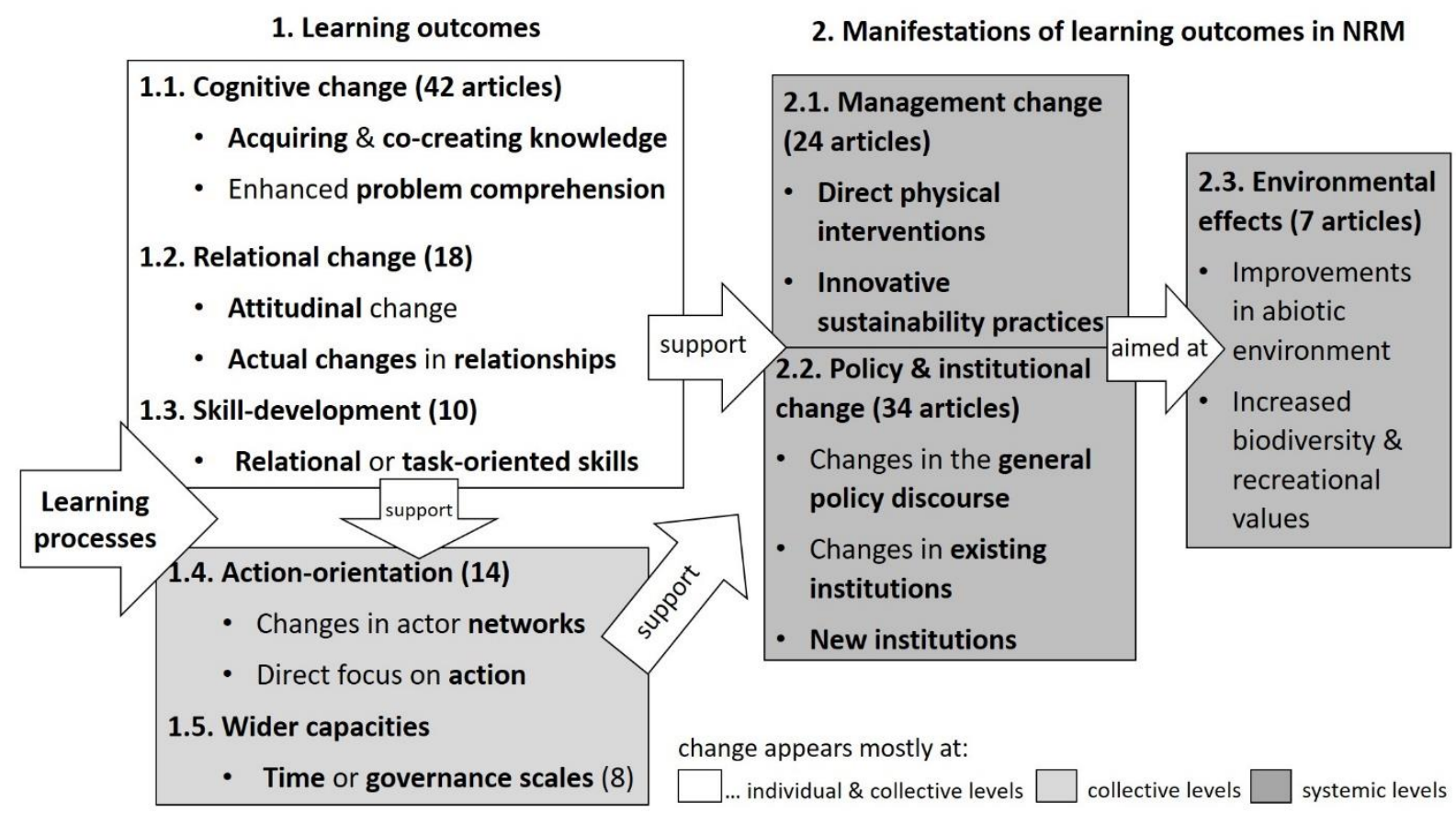

Figure 4. Synthesis framework: key themes emerging from the empirical literature across the outcome categories from learning processes. Note: Numbers in brackets denote the number of articles containing specific theme.

An assumption held by the scientific literature, as summarised in earlier reviews (Cundill and Rodela 2012), is that learning may enhance comprehension of the problem domain of key actors, and this would eventually affect management decisions. Several articles in our sample indicate an interest in this aspect. For example, Moellenkamp et al. (2010) describe how a better understanding of the interconnectedness of water management problems in the area led to envisioning of a plan to develop options for water discharge and an agreement to conduct a research experiment (Germany). Wallis et al. (2013) show how key water management actors began to recognise the salinity issue as 'wicked' problem, which led to the drafting of salinity management plans (Australia), while Cheng et al. (2011:91) describe how learning about the inter-connections between the ecological and the economic dimension resulted in community endeavours to "restore watershed health while employing community residents" in the USA. Therefore, while many of the included publications discuss shifts towards a systemic understanding, and several embedded that into the framework of multiple-loop learning, the links between learning and action are still rather unclear and generally underreported. In this regard, relevant insight is offered in the study by Vinke-de Kruijf et al. (2014) where they report on empirical cases from Romania and the Netherlands and discuss how improved understanding of the interdependencies between the social and ecological system does not always result in action. 
Although cognitive advancement is usually observed by studying individuals (Armitage et al. 2008; Marschke and Sinclair 2009), several publications in our sample explicitly refer to cognitive changes at the collective level. This trend is foremost evident in studies applying concepts like knowledge co-production (Armitage et al. 2011), knowledge integration (Hordijk et al. 2014), or communities of practice (Puente-Rodriguez et al. 2015). Several articles mention an increased collective awareness among the public and politicians about, e.g. climate-related challenges in Finland (Hilden 2011), flood risks in Sweden (Johannesen and Hahn 2013), or cyanide problems in Hungary (Sendzimir et al. 2010). Often publications refer to modifications in shared understandings (e.g. Bos and Brown 2012; Rist et al. 2007; Pahl-Wostl et al. 2013; Smith et al. 2015), which emerged over an extended period and embraced a reconceptualisation of a problem. For example:

"Through a lengthy self-organised process during 2001-2002 a common understanding of the complex nature of the urban storm-water management problem was created. Within this shared understanding, urban stormwater was viewed as a societal challenge instead of a purely technical problem. This differed substantially from what was standard practice at the time, where storm-water problems were a priori defined as either a flooding problem or a storm-water quality problem, which required an end-of-pipe solution" (Bos and Brown 2012:1343).

Cognitive change is often linked to other learning outcome categories, but also to learningrelated NRM manifestations (Table 2). The significance of cognitive advancement should thus not be underestimated since it can trigger a cycle of more fundamental and systemic changes towards more holistic understanding important for adaptive and transformative change (Armitage et al. 2012).

\subsubsection{Relational change}

A third of the included articles (18) describes relational changes as a type of learning outcome. A closer exploration of this subset revealed the emergence of two themes: (1) attitudinal changes towards stakeholders/actors, and (2) actual changes in relationships (Figure 4).

In our sample, articles referring to attitudinal change linked this outcome to stakeholders or actors. For instance, D'Angelo and Brunstein (2014) note how, within a Brazilian chemical company's network, more positive attitudes emerged among landowners and other actors towards recovering ciliary forests, over 23 years via a continued process of network-building. Several articles describe enhanced attitudes towards participatory action research and decisionmaking processes (e.g. Hordijk et al. 2014; Secco et al. 2011; Nguyen et al. 2014; Balazs and Lubell 2014).

Similarly as reported by Muro and Jeffrey $(2008 ; 2012)$ we also found multiple articles documenting actual changes in relationships, in terms of trust-building or communication and facilitated conflict resolution (Hahn et al. 2006; Hoverman et al. 2011; Sol et al. 2011). These themes were often connected to cognitive aspects, like gaining a better understanding of others' interests and viewpoints (Sims and Sinclair 2008; Menzel and Buchecker 2013), or acquiring a more critical understanding of one's own roles (Sinclair et al. 2013). Despite a widespread call to consider power relations more systematically in social learning studies (Armitage et al. 2012; Crona and Parker 2012; Hahn and Nykvist 2017), much in line with previous research (e.g. Van Bommel et al. 2009), only two of the reviewed articles mention changes in power relations as learning outcomes (Leys and Vanclay 2011; McDougall et al. 2013). 
Several of the included articles mention profound (i.e. transformative) change; the authors, however, remain reserved about its occurrence in reality. For example, Dana and Nelson (2012:247) note that learning resulted in new images of the others, giving a basis for new relationships but "not necessarily transformed relationships". Menzel and Buchecker (2013) record changed relationships among the participating actors in river restoration projects, but cast doubts about whether this change will last over time.

\subsubsection{Skill-development}

Ten of the reviewed articles (19\%) (Figure 4) refer to enhanced relational or task-oriented skills. We notice that often this concerns more general aspects, such as skills to deal with uncertainty (Armitage et al. 2011). Authors mention specific social skills, like enhanced communicative skills (Albert et al. 2012), or learning to lead participatory processes effectively (Menzel and Buchecker 2013). Task-oriented aspects in our sample concern e.g. skills on how to recover ciliary forests (D'Angelo and Brunstein 2014) or restore watershed health (Cheng et al. 2011) and technical skills on urban civic ecology practices (Tidball et al. 2010). Certain studies mention both types of skills (Sims and Sinclair 2008; Sinclair et al. 2013; Vinke-de Kruijf et al. 2014).

The acquisition of skills is emphasised, for example, in the theory about 'communities of practice' by E. Wenger (Pahl-Wostl et al. 2007). Five publications in our sample used this theory. Also, the two studies in our sample applying the concept of transformative learning explicitly refer to skill-development, e.g. problem-solving capacities in the context of participatory resource management programs (Sims and Sinclair 2008; Sinclair et al. 2013).

Existing literature on social learning only occasionally refers to skill-development as a key learning outcome (e.g. Keen and Mahanty 2005; Muro and Jeffrey 2012). However, skills seem to be decisive for changes in the NRM domain: all articles reporting on skills also report on such changes (Table 2).

\subsubsection{From learning to concerted action}

As indicated above, determining exact links between learning and sustainable practices is often a highly complicated task in social-ecological research (e.g. Plummer and Armitage 2007). (Reed et al. 2014) suggest that learning leads to concerted action under three conditions: knowledge co-creation, the building of relations of trust, and a change in practices and underlying institutions (norms and other rules). In our initial analytical framework, we asserted that specifically two learning outcomes - orientation to collective action (category 1.4 Figures 1 and 4), and wider capacities beyond specific initiatives (category 1.5) - facilitate further change. Our empirical analysis suggests that these outcomes indeed represent an important link between learning outcomes and their NRM manifestations. We elaborate on this in the next two sub-sections.

\subsubsection{Action-orientation}

We found aspects related to collective action in 14 (26\%) of the included articles. A closer investigation revealed two themes: (1) the development, or changes, in actor networks; and (2) the tendency to focus directly on action (Figure 4). 
Earlier research suggests that social networks may foster learning and adaptive co-management (Crona and Parker 2012; Plummer et al. 2013). It has been assumed that when social networks experience collective learning, this may, in turn, alter the network structure (e.g. nature of relations), but it may also change formal roles and institutions regulating the networks (Newig et al. 2010). However, existing research is contradictory at this point (cf. Henry and Vollan 2014) and the impact on learning seems to depend on different aspects, e.g. network structures. Some network characteristics may also be associated with contradicting outcomes (Newig et al. 2010). Social cohesion, for example, can prevent learning by fostering group thinking and closure. However, it can also support learning by enhancing trust and mutual understanding. Which kind of effect prevails may be influenced by other factors such as leadership or influence from other levels.

In our sample, several articles describe changes of the social network as learning outcome on its own. For instance, that includes new connections among stakeholder networks as those discussed by Moellenkamp et al. (2010), in relation to the participatory process focused on the Dhuenn basin management in Germany, or as those discussed by Sol et al. (2013) in relation to the action-research rural development project in the Netherlands. Huntjens et al. (2011), Sendzimir et al. (2010), and Pahl-Wostl et al. (2013) report about an informal 'shadow network' developed in the Tisza river basin, while Rist et al. (2007) describe how social networks expanded across rural governance in selected cases from India, Bolivia and Mali. However, action-orientation may, or may not, induce action. For example, in a case of empowerment of disadvantaged communities in the USA, Balazs and Lubell (2014:116) conclude that " [...] early signs of triple-loop learning were evident, though the adoption of lasting structural changes is, at best, only just beginning."

Many studies from our sample that refer to action relate to cognitive aspects too, as described above (category 1.1). For example, Hurlbert (2013) reports on the building of expertise to deal with complexity through learning within agri-environmental programmes in Saskatchewan, Canada. However, it is often difficult to detect exactly how learning catalyses action:

"All activities where stakeholders became an active part of the process, such as participatory monitoring and also the adapted problem definition and the altered goal definition, transformed stakeholders' room of action as they entered domains where they had not previously been active. Interviews show that these transformations of stakeholders' room of action were important for their willingness to act" (Alkan-Olsson et al. 2011:385).

\subsubsection{Wider capacities}

Social learning literature suggests that a more solid and empirically grounded understanding of social learning processes in the wider context (e.g. in a multi-level governance system) is needed to capture the essence of transformative change (Pahl-Wostl 2015). Indeed, cross-scale and cross-level dynamics and adjustments in governance systems are regarded as key aspects of social-ecological transformations, and notably also in differentiating between adaptive and transformative change (Brown 2014).

In our sample, eight articles (15\%) discuss wider capacities, i.e. enhanced capacities beyond the scope of specific interventions: aspects spanning across different levels at scales of time, but also governance or social organisation. These capacities are essential for building general resilience (Folke et al. 2010). For example, Albert et al. (2012) report on how stakeholders developed skills that transcend a single planning process in Germany and Armitage et al. (2011) 
observe how in co-management processes in Canada, capacities emerged to deal with uncertainty. Existing literature (e.g. Chaffin et al. 2014) suggests that functioning actor networks are essential to create cross-level and cross-scale linkages and establish 'a culture of learning' which in turn supports learning across multilevel governance structures. This concurs with our findings and the final category of learning outcomes (wider capacities, 1.5.).

Several studies in our sample discuss ways change could be sustained beyond interventions. For instance, Moellenkamp et al. (2010) discuss change beyond their project: participatory approaches were initially viewed as a new element in water management, but later as a regular way to implement the Water Framework Directive. Along similar lines, Rist et al. (2007) discuss ways to institutionalise social learning impacts to the level of community within its broader institutional context. Interestingly, all articles reporting on wider capacities also report on changes in NRM (Table 2).

\subsection{Manifestations of learning outcomes in the NRM domain}

A growing body of literature calls for a more systematic assessment of how learning affects NRM outcomes (Plummer and Armitage 2007), e.g. what is the impact of social learning on tangible development outcomes (Kristjanson et al. 2013). Although all 53 articles discuss learning in relation to NRM, we found tangible manifestations of learning outcomes referred to in $43(81 \%)$ articles (Table 2). Furthermore, about one-third (18) of the 53 articles report both, immediate learning outcomes and their NRM manifestations. Out of these, 10 articles discuss more than one outcome category in either of the two domains (learning outcomes or NRM manifestations).

\subsubsection{Management change}

In our sample, 24 articles (45\%) discuss changes in management practices, i.e. in the operational decisions targeted at specific goals (Armitage et al. 2012; Borrini-Feyerabend et al. 2006). A closer look at these helped to identify the following themes: (1) direct physical interventions; and (2) innovative sustainability practices (Figure 4).

First, several articles report changes in terms of concrete physical interventions in different NRM domains. These are sometimes coping mechanisms, i.e. mostly short-term oriented, immediate responses to environmental change (Speelman et al. 2014). For instance, Head (2014) reports on the building of a major pipeline network and a desalination plant as successful outcomes of policy learning. Often, included articles describe changes along multiple dimensions, e.g. Van Assche et al. (2013) present a wide variety of technological innovations in the ice fishing communities in the Lake Mille Lacs, MN, e.g. the quality of drills, fishing gear and ice roads as well as new solutions for heating, cooking, hygiene, sleeping, and entertainment in the ice shanties. The two publications relying on transformative learning theories link learning processes and the resulting collective action in a very direct way, as Sinclair et al. (2013:65) put it:

"The data also reveal that both communicative and instrumental learning outcomes resulted in social action contributions aimed at achieving more sustainable water practices among local farmers.” 
According to the existing literature (Speelman et al. 2014), such examples of outcomes as described above can be viewed as coping mechanisms: mostly short-term, immediate responses to environmental change.

Several publications describe iterative loops between the cognitive (1.1.) and action-oriented category (1.4.), resulting in decisions and NRM changes (e.g. Huntjens et al. 2011; Hurlbert 2013). Direct interventions (2.1) may catalyse policy or institutional change (2.2) or have wider capacities (1.5). For example, Pahl-Wostl et al. (2013) analyse how learning at local and regional levels promoted the initiation of floodplain restoration projects and polder constructions in the Rhine river basin in the Netherlands and Germany, which in turn affected decisions in the formal policy cycle. Illustrating wider capacities, Sendzimir et al. (2010:614615) describe the construction of the Cigand Polder as "a pilot test of floodplain storage of flood waters" in Hungary, which "raised and sustained awareness about alternative options to use floodplain revitalization for flood risk reduction and to boost farming".

Second, multiple publications discuss how learning leads to innovative sustainability practices, for instance, Cheng et al. (2011) report on silvo-pastoral projects in the US which try to generate income but also aim at positive ecological effects; Hahn et al. (2006) report about small conservation projects with considerable social and ecological effects in Sweden; while Sol et al. (2013) report on novel activities for integrated rural development in the Netherlands and Puente-Rodriguez et al. (2015) write about sustainability transitions of mussel fisheries in the (e.g. installation of spat collectors, closure areas for fishery). Tidball et al. (2010) discuss how stewardship actions, resulting from learning processes in urban civic ecology practices in the US, not only have a healing effect on the participants but also contribute to urban sustainability in a wider sense (category 1.5.). Such innovative practices could be considered as mechanisms to strengthen general resilience (Folke et al. 2010) and adaptation, in terms of deliberatively anticipating and addressing potential environmental and socio-economic challenges (Speelman et al. 2014).

\subsubsection{Policy and institutional change}

Almost two-thirds of the included articles (34) discuss policy and institutional outcomes of learning in the NRM domain. We identified three themes in this regard: (1) changing general policy discourse; (2) changing existing institutions; (3) creating new institutions (Figure 4).

In our sample, all reviewed publications relying on policy learning theories (seven articles), plus one relying on 'social learning', reported on certain kinds of policy change. It is useful to note that definitions of the concept 'policy learning' vary: sometimes the literature focuses on policy change as directly resulting from learning (e.g. Hall 1993), although other authors (e.g. Weible et al. 2012) warn that policy change should not be equated with learning. We observe that eight of the reviewed articles use a general discourse to report changes in policies at various organisational and governance levels. These changes concern modifications of the mainstream political idea in a specific domain (Rist et al. 2007; Secco et al. 2011; Sendzimir et al. 2010)). Several publications report this as shifts in ways in which issues are dealt with in different policies: for instance, changes in the Flemish forest policy (Van Gossum et al. 2008) or certain modifications in the Finnish climate policy, manifested in the ways in which the Kyoto mechanisms were treated over time: from uncertainties in 2001 to pilot efforts and an active use in 2008 (Hilden 2011). 
The second set of articles (9) relies on the construct of 'social learning', to report on newly created, or revised, policies or documents aimed at specific actions. The links between learning and NRM outcomes are often explicit. For example, Albert et al. (2012) report on a climate adaptation action-research project where workshops served as the basis for strategic planning. Bos and Brown (2012) present a similar case from Australia, where learning within a governance experimentation resulted in the development of a long-term community water vision and management plans. Several publications discuss the creation of management plans to solve concrete NRM problems, e.g. a management plan for organising collective Brazil nut sales (Biedenweg and Monroe 2013). There are, therefore, multiple and similar examples in water management domain in several countries, e.g. Sweden (Alkan-Olsson et al. 2011), Switzerland (Menzel and Buchecker 2013), Romania (Vinke-de Kruijf et al. 2014) or Brazil (Kumler and Lemos 2008).

Altered institutional arrangements are often regarded as more profound outcomes of intense learning experiences (Armitage et al. 2008). In our sample, 16 articles (31\%) indicate the creation of new institutions, including focusing on organisations for developing and implementing new policies. Some of these articles address more general governance issues, e.g. the establishment of a Man-And-Biosphere reserve in Kristianstad's Vattenrike, Sweden (Hahn et al. 2006), or the foundation of two new marine protected areas in the Bahamas (Wise 2014). Several articles refer to the setting up of new organisations. For instance, Cundill (2010) looks at how the Machubeni Section 21 Company - a legally recognised not-for-profit organisation - was formed from a co-management process in South Africa to develop and implement new institutions. Similarly, Van Assche et al. (2013) describe the emergence of a vast array of new businesses in the course of social learning processes, in the context of fisheries' comanagement, USA. Several publications in this group refer to the creation of statutory or advisory bodies, often formed on an ad hoc basis, such as the establishment of the Queensland Water Commission, a statutory body to centralise water strategy responsibilities in Australia (Head 2014); or the Vindan's water council in the Kaggebo river basin, Sweden (Alkan-Olsson et al. 2011). In some cases, the authors demonstrate a direct interest in certain wider capacities arising from learning (category 1.5), as Menzel and Buchecker (2013) put it:

"Regarding new institutions that were proposed as third-order effects, we identified two organizations that were created late in the processes, probably in the implementation phase or even after project implementation. One was an organization that brought conservationists and farmers together; the other one was a yearly symposium on water issues in the municipality that undertook the Flaz project."

In some articles, the institutional change meant reaching agreements, more or less formalised, targeted at resolving NRM conflicts. For example, Puente-Rodriguez et al. (2015) show how an agreement was achieved, in the form of signing a covenant between mussel fishers and the government, to gradually replace the unsustainable bottom-trawling with non-bottom dredging methods in the Netherlands. In a similar way, Boyd et al. (2014) describe novel solutions to environmental challenges, such as partnerships and other informal governance arrangements between the community and private actors for waste and water services in a climate governance case in Mozambique. However, Boyd et al. (2014:146) note that transformational change did not occur:

"It seems that many of these examples are evidence of incremental outcomes (as in Adger and Jordan, 2009) rather than of transformational social and political outcomes (as in Pelling, 2010).“ 
Certain publications discuss how a complex set of established informal and formal institutional arrangements are dealt with, e.g. in the case of Canadian Arctic co-management (Armitage et al. 2011) where institutional change meant how beluga whale (Delphinapterus leucas) entrapments were managed over time through quotas, seasonal no-take periods, and adjustments in population estimates using traditional knowledge. D'Angelo and Brunstein (2014) describe the development of a new systems-thinking and experience-oriented management model for developing sustainable businesses, in the context of agricultural management in Brazil. Examples of changes in formal institutions include the passage of several federal laws and policies benefiting community-based forestry in the USA (Cheng et al. 2011) and the implementation of a federal law and a new management system in the Brazilian water management case (Kumler and Lemos 2008). However, Cheng et al. (2011:94) conclude that a more profound change in the governance systems has not yet been achieved:

"Although we found ample evidence of social and policy learning regarding desired changes in constitutional-level forest governance, progress towards more significant reforms in constitutional-choice governance remains slow".

\subsubsection{Environmental effects}

Environmental outcomes are often regarded as the ultimate goal of learning-based approaches (Koontz et al. 2006; Plummer and Armitage 2007). Only 7 articles (13\%) explicitly reported on environmental outcomes connected to learning processes. Again, studies relying on the transformative learning concept (Sims and Sinclair 2008; Sinclair et al. 2013) link these outcomes in a relatively explicit way to learning processes:

"Instrumental learning, and the ensuing change in farming practice, was also shown to have tangible environmental and social benefits [in Costa Rica]. These include a reduction in agrochemical use, erosion, and operating costs" (Sims and Sinclair 2008:162).

However, some studies relying on the social and policy learning concepts use similar arguments. Hahn et al. (2006) report on an increase in biodiversity and recreation values, resulting from ecosystem-based management in Kristianstad, Sweden. In a similar manner, Wallis et al. (2013) argue how the salinity situation improved through concerted actions of stakeholders, in the context of water governance in Australia. Tidball et al. (2010) describe potential effects, noting that participants' stewardship actions in community forestry projects in the USA, combined with social learning processes, have a high potential to increase postcatastrophe ecosystem services provision resulting from learning.

Another set of studies (such as Armitage et al. 2011; Leys and Vanclay 2011) mention the overall importance of considering environmental outcomes in relation to learning, but note that these aspects were not explicitly addressed in their studies for different reasons, e.g. due to time constraints (long cycles of feedback loops, etc.). Alkan-Olsson et al. (2011) and Menzel and Buchecker (2013) explicitly seek to explore the links between learning and ecological conditions as part of their goal-setting and research design but do not find empirical evidence on the expected outcomes in this domain. 


\section{Conclusions}

As this review suggests, transdisciplinary empirical research that directly addresses learning outcomes, and their NRM manifestations, is expanding. We draw the following conclusions and reflections based on our synthesis.

First, our review mapped the diversity of different learning theories across the NRM research field. The analysis showed this to include not only the conceptual construct of 'social learning', but also theories of policy learning, transformative learning, and others. We described how the underlying assumptions of each theory, about who learns and how learning takes place, shapes the expectations about the type of outcomes and wider implications of the learning process. Authors discuss a more direct link between learning and NRM manifestations if they use policy learning theories. In contrast, in publications where the theory of transformative learning is applied, the authors tend to first link learning with outcomes learners acquired (e.g. skills), and, as a second step, connect those with NRM manifestations. Thus, there is conceptual diversity in learning-related NRM literature which needs to be addressed in future research on transformative change. We see the need for a unified terminology across different theories as this might allow for a more meaningful comparison across interventions and self-emerging processes, learning outcomes and their links to transformative change in NRM. In highlighting these differences our review gives a small contribution in that direction. However, since our review did not aim for a comparison, this is a task still to be accomplished by future research.

Second, most of the existing literature takes a normative stance and states that the ultimate goal of learning (in the context of NRM) should be concerted action towards sustainable practices (e.g. Schusler et al. 2003; Muro and Jeffrey 2008; 2012; Cundill and Rodela 2012). However, what kind of learning outcomes are needed for achieving this is still open to debate. Our review mapped selected literature and sought to gather evidence about such learning outcomes - which we chose to name: (1) action-orientation (category 1.4 in Figures 1 and 4) and (2) wider capacities beyond specific initiatives (category 1.5). The results that emerge from our analysis are mixed. Reviewed articles discussing aspects on action-orientation did not always report NRM manifestations. However, many articles in our sample refer to changes in actor networks (i.e. social networks) as part of action-orientation. Nevertheless, the details of this are often neglected in most of the social learning literature we reviewed here. More generally, there are few systematic studies of how social networks might have promoted, or hindered, learning in general and/or social learning. In relation to this, there are opportunities for future research to further deconstruct and conceptualise this aspect. Yet, not all scholars agree networks necessarily promote learning and action (e.g. Newig et al. 2010; Henry and Vollan 2014). Also, regarding wider capacities (category 1.5), the results we gathered are mixed. From our sample, only a few articles discussed the implications of learning across governance levels: an aspect that has been called upon to be considered in earlier research (e.g. Pahl-Wostl 2009), on sustained impacts over time, or on the building of adaptive capacity for different types of crises. This is also an area for future research, especially in the view of advancing our understanding of transformative change across multiple governance levels, different time scales and diverse contexts.

Third, we observed that the selected literature paid considerable attention to institutions that could potentially link learning and NRM outcomes. In our sample, many publications describe innovations related to both management interventions (category 2.1) and development of new institutions (category 2.2). Several of the reviewed articles report on not just new institutions 
created, but the establishing of a multi-stakeholder organisation. However, we also noticed that how well these then performed in practice, and how well managed to endure over time, is not very often subject to further discussions. This we believe is a missed opportunity. Information of this type is of an interest to practitioners working with real-world NRM issues in the field and it could help them while designing (and implementing) interventions meant to foster transformative change.

We conclude by pointing out two further important issues that our review does not address directly. The first concerns the aspect of 'non-outcomes' or 'negative' outcomes which our framework, and analysis. From our sample, 13 articles mentioned 'failures' of the learning processes, i.e. where the expected results were not achieved. For example, Head (2014) discusses deep policy changes that did not take place, Madsen and Noe (2012) comment on limited changes in identities, while Puszkin and Esnard (2009) discuss learning not leading to the expected policy reform. Contemporary learning literature (especially on social learning) most often focuses on presenting successful case studies, however, exploring and learning from 'failure' could reveal impediments to learning success. The second aspect concerns choices of research methodology, and how this impacts the opportunities to investigate learning outcomes. Earlier research, and our review, has indicated that learning processes can be externally induced (e.g. action-research or government-supported decision-making) or internally initiated via selforganising networks of actors. Future research could look at which types of outcomes these methodological approaches tend to support.

\section{Acknowledgements}

We are grateful to Joanne Vinke-de Kruijf and Geeske Scholz for useful comments on earlier versions of this manuscript. We would also like to thank two anonymous reviewers for their valuable remarks that have helped us to refine this work.

\section{Funding}

The first author wishes to thank the Swedish Institute for a one-year visiting scholar grant to work at Stockholm Resilience Centre, Sweden. Preliminary results of this manuscript have been presented at the IST 2016 conference in Wuppertal, Germany, for which the first author received a mobility grant from SA Archimedes. Our research has been co-financed by Mistra through a core grant to Stockholm Resilience Centre. Part of the work undertaken by Romina Rodela was funded under a grant from the Foundation for Baltic and East European Studies (Östersjöstiftelsen).

\section{Supplemental data}

Supplemental data for this article can be accessed at https://doi.org/10.1080/09640568.2017.1339594. 


\section{References}

Armitage, D., Loe, R., and Plummer, R. 2012. "Environmental governance and its implications for conservation practice." Conservation Letters 5: 245-255.

Armitage, D., Marschke, M., and Plummer, R. 2008. "Adaptive co-management and the paradox of learning." Global Environmental Change 1: 86-98.

Baird, J., Plummer, R., Haug, C., and Huitema, D. 2014. "Learning Effects of Interactive Decision-making Processes for Climate Change Adaptation." Global Environmental Change 27: 51-63.

Barnett-Page, E., and Thomas, J. 2009. "Methods for the synthesis of qualitative research: a critical review." BMC Medical Research Methodology 9: 59.

Bennett, C., and Howlett, M. 1992. "The lessons of learning: Reconciling theories of policy learning and policy change." Policy Sciences 25: 275-294.

Berkes, F. 2009. "Evolution of co-management: role of knowledge generation, bridging organizations and social learning." Journal of Environmental Management 90: 1692-1702.

Borrini-Feyerabend, G., Johnston, J., and Pansky, D. 2006. "Governance of Protected Areas." In: Lockwood, M., Worboys, G., and Kothary, A. (Eds.). Managing Protected Areas: A Global Guide. Gland, Switzerland and London: IUCN and Earthscan: 116-146.

Bromley, D. 1991. Environment and economy: property rights and public policy. London: Basil Blackwell.

Brown, K. 2014. “Global environmental change I: A social turn for resilience?" Progress in Human Geography 38(1): 107-117.

Brugnach, M., and Ingram, H. 2012. "Ambiguity: the challenge of knowing and deciding together." Environmental Science and Policy 15: 60-71.

Bull, R., Petts, J., and Evans, J. 2008. "Social learning from public engagement: dreaming the impossible?" Journal of Environmental Planning and Management 51(5): 701-716.

Carroll, C., Booth, A., Leaviss, J., and Rick, J. 2013. "Best Fit" Framework Synthesis: Refining the Method." BMC Medical Research Methodology 13: 37.

Chaffin, B., Gosnell, H., and Cosens, B. 2014. "A decade of adaptive governance scholarship: synthesis and future directions." Ecology and Society 19 (3): 56.

Crona, B., and Parker, J. 2012. "Learning in support of governance: theories, methods, and a framework to assess how bridging organizations contribute to adaptive resource governance." Ecology and Society 17(1): 32.

Cundill, G., and Rodela, R. 2012. "A review of assertions about the processes and outcomes of social learning in natural resource management." Journal of Environmental Management 113: 7-14.

Dedeurwaerdere, T. 2009. "Social learning as a basis for cooperative small-scale forest management." Small-Scale Forestry 8(2): 193-209. 
Diduck, A., Sinclair, J., Hostetler, G., and Fitzpatrick, P. 2012. "Transformative Learning Theory, Public Involvement, and Natural Resource and Environmental Management." Journal of Environmental Planning and Management 55(10): 1311-1330.

Ensor, J., and Harvey, B. 2015. "Social learning and climate change adaptation: evidence for international development practice." WIREs Climate Change 6: 509-522.

Fabricius, C., and Cundill, G. 2014. "Learning in adaptive management: insights from published practice." Ecology and Society 19(1): 29.

Folke, C., Carpenter, S. R., Walker, B., Scheffer, M., Chapin, T., and Rockström, J. 2010. "Resilience Thinking: Integrating Resilience, Adaptability and Transformability." Ecology and Society 15(4): 20.

Folke, C., Hahn, T., Olsson, P., and Norberg, J. 2005. "Adaptive governance of socialecological systems." Annual Review of Environment and Resources 30(1): 441-473.

Gerlak, A., and Heikkila, T. 2011. "Building a Theory of Learning in Collaboratives: Evidence from the Everglades Restoration Program." Journal of Public Administration Research and Theory 21: 619-44.

Haddaway, N., Woodcock, P., Macura, B., and Collins, A. 2015. "Making Literature Reviews More Reliable through Application of Lessons from Systematic Reviews." Conservation Biology 29(6): 1596-1605.

Hahn, T. 2011. "Self-organized governance networks for ecosystem management: who is accountable?" Ecology and Society 16(2): 18.

Hahn, T., and Nykvist, B. 2017. "Are adaptations self-organized, autonomous and harmonious? Assessing the social-ecological resilience literature.” Ecology and Society 22(1): 12.

Hall P.A. 1993. "Policy Paradigms, Social Learning, and the State: The Case of Economic Policymaking in Britain.” Comparative Politics 25(3): 275-296.

Hannes, K., and Lockwood, M. 2012. Synthesizing qualitative research: Choosing the right approach. Oxford: Wiley-Blackwell.

Henry A.D., Vollan, B. 2014. "Networks and the challenge of sustainable development." Annual Review of Environment and Resources 39 (1): 583-610.

Ison, R., Collins, K., and Wallis, P. 2015. "Institutionalising social learning: Towards systemic and adaptive governance." Environmental Science and Policy 53: 105-117.

Keen, M., and Mahanty, S. 2005. "Learning in Sustainable Natural Resource Management: Challenges and Opportunities in the Pacific." Society \& Natural Resources 19(6): 497-513.

Kristjanson, P., Harvey, B., Van Epp, M., and Thornton, P. 2013. "Social Learning and Sustainable Development." Nature Climate Change 4(1): 5-7.

Koontz, T., and Thomas, C. 2006. "What Do We Know and Need to Know about the Environmental Outcomes of Collaborative Management?" Public Administration Review: Environmental Outcomes of Collaborative Management (Special Issue, December 2006), 111-120. 
Marschke, M., and Sinclair, J. 2009. "Learning for sustainability: Participatory resource management in Cambodian fishing villages." Journal of Environmental Management 90: 206-216.

Mezirow, J. 1991. Transformative dimensions of adult learning. Jossey-Bass: San Francisco.

Mostert, E., Pahl-Wostl, C., Rees, I., Searle, B., Tàbara, D., and Tippett, J. 2007. "Social Learning in European River-Basin Management: Barriers and Fostering Mechanisms from 10 River Basins." Ecology and Society 12(1): 19.

Muro, M., and Jeffrey, P. 2008. "A critical review of the theory and application of social learning in participatory natural resource management processes." Journal of Environmental Planning and Management 5 (3): 325-344.

Muro, M., and Jeffrey, P. 2012. "Time to Talk? How the Structure of Dialog Processes Shapes Stakeholder Learning in Participatory Water Resources Management.” Ecology and Society 17(1): 3 .

Newig, J., Günther, D. and Pahl-Wostl, C. 2010. "Neurons in the network: Learning in Governance Networks in the Context of Environmental Management." Ecology and Society 15(4): 24.

Paavola, J. 2007. "Institutions and environmental governance: A reconceptualization." Ecological Economics 63: 93-103.

Pahl-Wostl, C., Craps, M., Dewulf, A., Mostert, E., Tabara, D., and Taillieu, T. 2007. "Social learning and water resources management." Ecology and Society 12(2): 5.

Pahl-Wostl, C. 2009. "A conceptual framework for analysing adaptive capacity and multi-level learning processes in resource governance regimes." Global Environmental Change 19: 354-365.

Pahl-Wostl, C. 2015. Water Governance in the Face of Global Change. From Understanding to Transformation. New York: Springer.

Paterson, B. 2012. ““It looks great but how do I know if it fits?": an introduction to metasynthesis research." In: Hannes, K., and Lockwood, C., (Eds.) 2012. Synthesizing Qualitative Research: Choosing the Right Approach. Chichester: Wiley-Blackwell: 1-15.

Petticrew, M., and Roberts, H. 2006. Systematic Reviews in the Social Sciences: A Practical Guide. Oxford: Blackwell.

Plummer, R., and Armitage, D. 2007. “A resilience-based framework for evaluating adaptive co-management: Linking ecology, economics and society in a complex world." Ecological Economics 61: 62-74.

Plummer, R., Armitage, D., and de Loë, R.C. 2013. "Adaptive co-management and its relationship to environmental governance." Ecology and Society 18(1): 21.

Reed, M., Godmaire, M., Abernethy, P., and Guertin, M-A. 2014. "Building a Community of Practice for Sustainability: Strengthening Learning and Collective Action of Canadian Biosphere Reserves through a National Partnership." Journal of Environmental Management 145: 230-239. 
Rodela, R. 2011. "Social Learning and Natural Resource Management: The Emergence of Three Research Perspectives." Ecology and Society 16(4): 30.

Rodela, R. 2013. "The social learning discourse: Trends, themes and interdisciplinary influences in current research.” Environmental Science and Policy 25: 157-166.

Rodela, R. 2014. "Social Learning, Natural Resource Management, and Participatory Activities: A reflection on construct development and testing." NJAS - Wageningen Journal of Life Sciences 69: 15-22.

Schultz, L., Folke, C., and Olsson, P. 2007. "Enhancing ecosystem management through socialecological inventories: lessons from Kristianstads Vattenrike, Sweden." Environmental Conservation 34(2): 140-152.

Schusler, T., Decker, D., and Pfeffer, M. 2003. "Social Learning for Collaborative Natural Resource Management.” Society \& Natural Resources 15: 309-326.

Siebenhüner, B., Rodela, R., and Ecker, F. 2016. "Social learning research in ecological economics: A survey." Environmental Science and Policy 55: 116-126.

Sinclair, J. Diduck, A., and Fitzpatrick, P. 2008. "Conceptualizing learning for sustainability through environmental assessment: critical reflections on 15 years of research." Environmental Impact Assessment Review 28: 415-428.

Sotirov, M., and Memmler, M. 2012. "The Advocacy Coalition Framework in natural resource policy studies - Recent experiences and further prospects." Forest Policy and Economics 16: 51-64.

Speelman, E.N., Groot, J.C.J., García-Barrios, L.E., Kok, K., van Keulen, H., and Tittonell, P. 2014. "From Coping to Adaptation to Economic and Institutional Change - Trajectories of Change in Land-use Management and Social Organization in a Biosphere Reserve Community, Mexico." Land Use Policy 41: 31-44.

Van Bommel, S., Röling, N., Aarts, N., and Turnhout, E. 2009. "Social Learning for Solving Complex Problems: a Promising Solution or Wishful Thinking? A Case Study of Multi-actor Negotiation for the Integrated Management and Sustainable Use of the Drentsche Aa Area in the Netherlands." Environmental Policy and Governance 19(6): 400-412.

Van Boxtel, C., van der Linden, J., and Kanselaar, G. 2000. "Collaborative learning tasks and the elaboration of conceptual knowledge." Learning and Instruction 10: 311-330.

Weible C. M., Heikkila, T., deLeon, P. and Sabatier, P. A. 2012. "Understanding and influencing the policy process." Policy Sciences 45: 1-21.

Wilner, K.B., Wiber, M., Charles, A., Kearney, J., Landry, M., and Wilson, L. 2012. "Transformative Learning for Better Resource Management: The Role of Critical Reflection.” Journal of Environmental Planning and Management 55(10): 1331-1347. 


\section{Additional references for the reviewed publications}

Albert, C., Zimmermann, T., Knieling, J., and von Haaren, C. 2012. „Social learning can benefit decision-making in landscape planning: Gartow case study on climate change adaptation, Elbe valley biosphere reserve." Landscape \& Urban Planning 105(4): 347-360.

Alkan-Olsson, J., Jonsson, A. C., Andersson, L., and Arheimer, B. 2011. "A model-supported participatory process for nutrient management: a socio-legal analysis of a bottom-up implementation of the EU Water Framework Directive." International Journal of Agricultural Sustainability 9(2): 379-389.

Armitage, D., Berkes, F., Dale, A., Kocho-Schellenberg, E., and Patton, E. 2011. „Comanagement and the co-production of knowledge: Learning to adapt in Canada's Arctic." Global Environmental Change-Human \& Policy Dimensions 21(3): 995-1004.

Balazs, C.L., and Lubell, M. 2014. "Social learning in an environmental justice context: a case study of integrated regional water management." Water Policy 16: 97-120.

Benson, D., Lorenzoni, I., and Cook, H. 2016. "Evaluating social learning in England flood risk management: An 'individual-community interaction' perspective.” Environmental Science \& Policy 55 (2): 326-334.

Biedenweg, K., and Monroe, M. 2013. „Teasing Apart the Details: How Social Learning can Affect Collective Action in the Bolivian Amazon." Human Ecology 41 (2): 239-253.

Bos, J.J., and Brown, R.R. 2012. "Governance experimentation and factors of success in sociotechnical transitions in the urban water sector." Technological Forecasting and Social Change 79(7): 1340-1353.

Boyd, E., Ensor, J., Broto, V.C., and Juhola, S. 2014. "Environmentalities of urban climate governance in Maputo, Mozambique." Global Environmental Change-Human \& Policy Dimensions 26: 140-151.

Cheng, A.S., Danks, C., and Allred, S.R. 2011. "The role of social and policy learning in changing forest governance: An examination of community-based forestry initiatives in the US." Forest Policy \& Economics 13(2): 89-96.

Cundill, G. 2010. "Monitoring Social Learning Processes in Adaptive Comanagement: Three Case Studies from South Africa." Ecology \& Society 15(3).

d'Angelo, M. J., and Brunstein, J. 2014. „Social learning for sustainability: supporting sustainable business in Brazil regarding multiple social actors, relationships and interests." International Journal of Sustainable Development and World Ecology 21(3): 273-289. doi:10.1080/13504509.2014.902868

Dana, G.V., and Nelson, K.C. 2012. "Social Learning Through Environmental Risk Analysis of Biodiversity and GM Maize in South Africa. Environmental Policy \& Governance 22(4): $238-252$.

Hahn, T., Olsson, P., Folke, C., and Johansson, K. 2006. 'Trust-building, knowledge generation and organizational innovations: The role of a bridging organization for adaptive comanagement of a wetland landscape around Kristianstad, Sweden. Human Ecology 34 (4): $573-592$.

Head, B.W. 2014. "Managing urban water crises: adaptive policy responses to drought and flood in Southeast Queensland, Australia." Ecology \& Society 19(2).

Hilden, M. 2011. "The evolution of climate policies - the role of learning and evaluations." Journal of Cleaner Production 19(16): 1798-1811. 
Hordijk, M., Miranda Sara, L., and Sutherland, C. 2014. "Resilience, transition or transformation? A comparative analysis of changing water governance systems in four southern cities." Environment and Urbanization 26(1): 130-146.

Hoverman, S., Ross, H., Chan, T., and Powell, B. 2011. "Social Learning through Participatory Integrated Catchment Risk Assessment in the Solomon Islands.” Ecology and Society 16 (2).

Huntjens, P., Pahl-Wostl, C., Rihoux, B., Schlueter, M., Flachner, Z., Neto, S., . . Kiti, I. N. 2011. "Adaptive Water Management and Policy Learning in a Changing Climate: a Formal Comparative Analysis of Eight Water Management Regimes in Europe, Africa and Asia." Environmental Policy and Governance 21(3).

Hurlbert, M. 2013. "Learning, participation, and adaptation: exploring agri-environmental programmes." Journal of Environmental Planning and Management 58(1): 113-134.

Johannessen, A., and Hahn, T. 2013. "Social learning towards a more adaptive paradigm? Reducing flood risk in Kristianstad municipality, Sweden." Global Environmental Change 23: $372-381$.

Kumler, L.M., and Lemos, M.C. 2008. "Managing Waters of the Paraiba do Sul River Basin, Brazil: a Case Study in Institutional Change and Social Learning." Ecology and Society 13(2).

Lebel, L., Grothmann, T., and Siebenhuener, B. 2010. "The role of social learning in adaptiveness: insights from water management." International Environmental AgreementsPolitics Law and Economics 10(4): 333-353.

Lee, E., and Krasny, M.E. 2015. "The role of social learning for social-ecological systems in Korean village groves restoration." Ecology and Society 20(1).

Leys, A.J., and Vanclay, J.K. 2011. "Social learning: A knowledge and capacity building approach for adaptive co-management of contested landscapes." Land Use Policy 28(3): 574-584.

Madsen, M. L., and Noe, E. 2012. "Communities of practice in participatory approaches to environmental regulation. Prerequisites for implementation of environmental knowledge in agricultural context." Environmental Science \& Policy 18: 25-33.

Maynard, C. 2015. "Accessing the environment: Delivering ecological and societal benefiits through knowledge integration - The case of water management." Applied Geography 58: 94-104.

McDougall, C., Jiggins, J., Pandit, B.H., Rana, S.K.T.M., and Leeuwis, C. 2013. "Does Adaptive Collaborative Forest Governance Affect Poverty? Participatory Action Research in Nepal's Community Forests.” Society \& Natural Resources 26(11): 1235-1251.

Menzel, S., and Buchecker, M. 2013. "Does Participatory Planning Foster the Transformation Toward More Adaptive Social-Ecological Systems?” Ecology and Society 18(1).

Moellenkamp, S., Lamers, M., Huesmann, C., Rotter, S., Pahl-Wostl, C., Speil, K., and Pohl, W., 2010. "Informal Participatory Platforms for Adaptive Management. Insights into Nichefinding, Collaborative Design and Outcomes from a Participatory Process in the Rhine Basin." Ecology and Society, 15(4).

Murillo, J.D., Norris, L., and Biernacki, J.J. 2015. "The Southern Grassroots Biofuels Project: A Participatory Study of Conservationists and Stakeholders From Two Upper Cumberland Counties." Sociological Spectrum 35(4): 349-371.

Nguyen, T-P., Seddaiu, G., and Roggero, P.P. 2014. "Hybrid knowledge for understanding 
complex agri-environmental issues: nitrate pollution in Italy." International Journal of Agricultural Sustainability 12(2): 164-182.

Nykvist, B. 2014. "Does Social Learning Lead to Better Natural Resource Management? A Case Study of the Modern Farming Community of Practice in Sweden." Society \& Natural Resources 27(4): 436-450.

Olsson, P., Folke, C., and Hahn, T. 2004. "Social-ecological transformation for ecosystem management: the development of adaptive co-management of a wetland landscape in southern Sweden." Ecology and Society 9(4).

Pahl-Wostl, C., Becker, G., Knieper, C., and Sendzimir, J. 2013. "How multilevel societal learning processes facilitate transformative change: a comparative case study analysis on flood management." Ecology and Society 18(4).

Puente-Rodriguez, D., Swart, J.A.A., Middag, M., and Van der Windt, H.J. 2015. "Identities, Communities, and Practices in the Transition Towards Sustainable Mussel Fishery in the Dutch Wadden Sea.” Human Ecology 43(1).

Puszkin-Chevlin, A., and Esnard, A.-M. 2009. "Incremental evolution and devolution of Florida's Coastal High Hazard Area policy." Journal of Environmental Planning and Management 52(3): 297-313.

Rist, S., Chidambaranathan, M., Escobar, C., Wiesmann, U., and Zimmermann, A. 2007. "Moving from sustainable management to sustainable governance of natural resources: The role of social learning processes in rural India, Bolivia and Mali." Journal of Rural Studies 23(1): 23-37.

Schneider, F., Steiger, D., Ledermann, T., Fry, P., and Rist, S. 2012. „No-tillage farming: cocreation of innovation through network building." Land Degradation \& Development, 23(3): 242-255.

Secco, L., Pettenella, D., and Gatto, P. 2011. "Forestry governance and collective learning process in Italy: Likelihood or utopia?" Forest Policy and Economics 13(2): 104-112. doi:10.1016/j.forpol.2010.04.002

Sendzimir, J., Flachner, Z., Pahl-Wostl, C., and Knieper, C. 2010. „Stalled regime transition in the upper Tisza River Basin: the dynamics of linked action situations." Environmental Science \& Policy 13(7): 604-619.

Shaw, A., and Kristjanson, P. 2014. "A Catalyst toward Sustainability? Exploring Social Learning and Social Differentiation Approaches with the Agricultural Poor." Sustainability 6(5): 2685-2717.

Sims, L., and Sinclair, A.J. 2008. "Learning through participatory resource management programs: Case studies from Cost Rica." Adult Education Quarterly 58(2): 151-168.

Sinclair, A.J., Kumnerdpet, W., and Moyer, J.M. 2013. "Learning sustainable water practices through participatory irrigation management in Thailand." Natural Resources Forum 37(1): $55-66$.

Smith, J., DuBois, B., and Krasny, M. 2015. "Framing for resilience through social learning: impacts of environmental stewardship on youth in post-disturbance communities." Sustainability Science, doi: 10.1007/s11625-015-0348-y

Sol, J., Beers, P., and Wals, A. 2013. "Social learning in regional innovation networks: trust, commitment and reframing as emergent properties of interaction." Journal of Cleaner Production 49: 35-43. 
Tidball, K. G., Krasny, M. E., Svendsen, E., Campbell, L., and Helphand, K. 2010. "Stewardship, learning, and memory in disaster resilience." Environmental Education Research 16 (5-6): 591-609.

Van Assche, K., Beunen, R., Holm, J., and Lo, M. 2013. "Social learning and innovation. Ice fishing communities on Lake Mille Lacs." Land Use Policy 34: 233-242.

Van Gossum, P., Ledene, L., Arts, B., De Vreese, R., and Verheyen, K. 2008. 'Implementation failure of the forest expansion policy in Flanders (Northern Belgium) and the policy learning potential." Forest Policy and Economics 10 (7-8): 515-522.

Vinke-de Kruijf, J., Bressers, H., and Augustijn, D.C.M. 2014. "How social learning influences further collaboration: experiences from an international collaborative water project." Ecology and Society 19(2).

Wallis, P.J., Ison, R.L., and Samson, K. 2013. "Identifying the conditions for social learning in water governance in regional Australia." Land Use Policy 31: 412-421.

Watanabe, M., da Rosa Gama Madruga, L. R., Yamaguchi, C. K., Pinto Vieira, A. C., and Jenoveva-Neto, R. 2014. "Decision Making and Social Learning: the Case of Watershed Committee of the State of Rio Grande do Sul, Brazil." Water Resources Management 28(11): 3815-3828.

Wise, S.P. 2014. "Learning through experience: Non-implementation and the challenges of protected area conservation in The Bahamas." Marine Policy 46: 111-118.

Yuen, E., Jovicich, S.S., and Preston, B.L. 2013. "Climate change vulnerability assessments as catalysts for social learning: four case studies in south-eastern Australia." Mitigation and Adaptation Strategies for Global Change 18(5): 567-590. 